https://dx.doi.org/10.4314/iijikm.v10i1.5

Information Impact:

Journal of Information and Knowledge Management

Vol. 10 (1), June, 2019

ISSN: 2141-4297 (Print) ISSN: 2360-994X (Online)

\title{
Acquisition of Information and Communication Technology Competencies by Distance Learners for Effective Utilization of Library Resources in NOUN Study Center Libraries in South East, Nigeria
}

\author{
Patricia Ngozi Ofodu \\ University Library, National Open University of Nigeria Abuja \\ ofodupat05@yahoo.com/ofodupat@gmail.com
}

\begin{abstract}
ICT competencies for learners are highly encouraged for enhancement of communication between the instructor and the learner and for information retrieval. The study is aimed at ascertaining the level of acquisition of information and communication technology competencies by distance learners for effective utilization of library resources in National Open University of Nigeria (NOUN) study center libraries in south east. The research was guided by three research questions. The design adopted for this study was descriptive survey. The sample size is 391 but completed and returned questionnaire is 365. Data collected was analysed using frequency table and simple percentages. Findings from the study reveal that learners possess the ICT competencies. Problems militating the effective utilization of library resources were identified and strategies for enhancement. Recommendations include the provision of constant electricity as a basic necessity for the working of ICT tools, organization of workshops/orientations/seminars on the use of ICT in utilizing library resources, among others.
\end{abstract}

Keywords: Acquisition, ICT Competencies, Distance Learners, Libraries, Library resources.

\section{Introduction}

Education contributes immensely to the growth of both the individual and society that is why it is imperative to have it even at its minimal. This led to the emerging glory of open and distance learning which is to assist people that are in serious need of education, who have missed such great opportunity in the past, to make it up. It is therefore the system of teaching and learning where the student is separated from the instructor by physical distance, but often bridged by communication technologies. Olubor and Ogonor (2008) opined that open and distance learning is a type of learning 
whereby opportunity is given to people, who have passed the ages of admission into regular universities to continue their education. They further express that it is also directed at youngsters beyond school age, who desire to earn a university degree. Open and distance learning is not only for old people, rather it is universal, for everybody that are privileged to meet up with past denied opportunity. Nwezeh (2010) added that open and distance education is often described as the formalized learning received while the student is on a location outside the university campus using ICT, it is a highly pre-packaged text, audio, and video courses taken by an isolated learner with limited/without interaction with an instructor or other students

Due to its importance, Oblinger, (2000) identified some rationale behind the establishment of open university education, as to expand access; alleviate capacity constraints; capitalizing on emerging market opportunities and serving as a catalyst for institutional transformation. The Federal Republic of Nigeria (2013) through its National Policy on Education detailed that the objectives of distance education should be to provide access to excellent education and equity in educational opportunities for those who otherwise would have been denied; meet the special needs of employers by instituting special certificate courses for their employees at their work place; encourage internationalization especially of tertiary education curricula and restructure the effect of internal and external brain drain in tertiary institutions by utilizing Nigerian experts as teachers regardless of their locations or places of work. The increasing demand for distance education programme in Nigeria led to the establishment of National Open University of Nigeria among other distance education institutions.

National Open University of Nigeria (NOUN) was first established in July 1983 and was closed down in 1984 and further reestablished on April 2001, few years after its closure. Presently NOUN has 78 Study Centres, which are located in the state capitals, major and important communities in all the six geo-political zones of the country, as well as the Federal Capital Territory (FCT). This study covers the selected study centers in the South East (Abia, Anambra, Enugu and Imo) States.

NOUN University Library was established in 2007, few years after the inception of the university. The main headquarter library was the first to be established, after which there were center libraries in the various study centers, for the benefits of the distance learners, in spite of the locality. Electronic information usage in the library include electronic information materials and services in the form of CDROMS, e-books, e-databases, electronic journals, electronic current awareness service and information subject gateways, accessed through the internet. Students ought to utilize these resources for quality research and study. Gakibayo, IkojaOdongo, and Okello-Obura. (2013) opined that the emergence of electronic information resources has tremendously transformed information handling and management in academic environments and in university libraries in particular. Modern ICT facilities enhance usage of the electronic information resources, if proper ICT skills are acquired, 
because it gives the library users the urge to constantly work on the computer and this brings about mastery. There is need to equip users with skills such as information literacy skills, information retrieval skills, computer skills among others as a strategy to promote e-resource usage especially among students in academic libraries for effective utilization of e-resources ( Gakibayo; Ikoja-Odongo \& Okello-Obura, 2013).

NOUN Library subscribes to several electronic databases for the availability of electronic books, journals and periodicals, and provides access links for its patrons in all the centre libraries, including the ones under study. Such e- resources are thus: Africa portal, the electronic library of mathematics, electronic resources for research methods, electronic journal of statistics, journal of entrepreneurial finance, national academic press, JSTOR, African journal archive, library and information science commons, e-prints in library \& information science and African digital library among others.

To highly explore these databases and utilize of the resources, ICT competencies are of paramount importance for effective utilization of library resources. Such skills needed by NOUN library users for information search and retrieval include: familiarity with the keyboard and being able to control the mouse properly; improved skills in word-processing techniques, especially file and folder creation, copying items, changing font sizes, shading, saving files and printing documents; improving communication skills especially through Internet browsing and information searching; calculations using Microsoft excel, database design and management. These skills if acquired ought to assist users for information access, retrieval and use. Omoniyi and Akinboro (2009) opine that there is need for acquisition of skills and competence in the use of ICT by both library staff and clientele for quality and efficient information service delivery and information search and retrieval by the library staff and library users respectively

Information and communication technology (ICT) is an act of using hardware and software in processing data to information for the purpose of storing, retrieving, manipulation and disseminating to the end user. Development in electronic information resources and communications systems, are the basic building blocks of modern libraries. Michael (2004) regards Information and communication technology as application of computer - based information systems using telephones, televisions, radios, computers and computer software to convert, store, process, protect and transmit information. Afolabi and Abidoye (2012) stated that their applications of ICT in libraries, commonly known as library automation, have indeed continued to ease and promote quick and timely access to and transfer of information resources that are found round the globe. Kamba (2011) asserted that faculty members, students, practitioners those involved in information services need to be sufficiently equipped with ICT competencies that will help them to handle both the users of information and the use of technologies in the information search, provision and management.

The library users need to acquaint themselves with the relevant skills (ICT 
competencies) to access the needed information. Pinpointing more on how ICT will enhance the utilization of library resources and services by users, Dodia (2012) identified some ICT competencies as follows: ICT Basic; Word processing;

\section{Objectives of the Study}

This study aims at determining the:

1. extent to which the distance learners possess ICT competencies for effective utilization of library resources in NOUN study centre libraries in South East.

\section{Research Questions}

The study will be guided by the following research questions:

1. To what extent do distance learners' possess the ICT competencies for effective utilization of library resources in NOUN study centre libraries in South -East?

2. What are the problems that militating against the acquisition of ICT

\section{Literature Review}

The right information must be available for the right person at the right time in their appropriate formats, which are the responsibilities of the library, librarian and the library management. Oguntuase and Falaiye (2004) agreed with this view by observing that the most effective way to mobilize clientele in the use of information resources, is through the provision of needed and required information in the most useable
Database; Internet surfing; Spreadsheet (Excel); Presentation /Computer and ethics/ Security ICT Competencies. The use of ICT is inevitable for any library user in modern times; it is a driving force for information accessibility and utilization.

2. the problems that militate against acquisition of ICT competencies for effective utilization of library resources in NOUN study centre libraries in South- East.

3. strategies for enhancing learners' ICT competencies for effective utilization of library resources in NOUN study centre libraries in South East.

competencies for effective utilization of library resources in NOUN study centre libraries in South- East?

3. What are the strategies for enhancing learner's ICT competencies for effective utilization of library resources in NOUN study centre libraries in the South East?

form and such information should be provided for the beneficial community. Library resources are of importance to even distance learners, especially the electronic resources, where ICT is paramount for its accessibility. Akudolu (2006) asserted that ICT competencies involve knowledge of skills, knowledge of how and when to apply the skills as well as knowledge of reasons for using the particular ICT or the 
contributions of that ICT to the solution of problem. In the word of today, ICT has really helped in the proper utilization of information for its benefits.

ICT enables sharing of resources, communicate and learn, which allows distance learners to study at their own pace, time and place. Blurton (2002) argued that if equipped with a computer, appropriate software, and internet access, students will have access to hundreds and thousands of information archives, and webpages of educationally relevant content. He further emphasised that the Internet represents the greatest collection of human knowledge ever assembled, and it is available to every student, teacher and researcher properly equipped with ICT.

Several ICT facilities enhance effectiveness in library resources access and utilization, Afolabi, and Abidoye (2011) discussed the ICT facilities as the computer, video conferencing, internet facility, electronic mail (E-mail), computer networking, and the expert system. Chauhan, (2004) also opined that skill acquired through ICT has tremendously changed the management of resources / House Keeping Operations like acquisition, cataloguing, circulation control, serials control etc.; He is with the emphasis that internet has been used extensively as a resource and a tool to deliver services in the Library and Information centers.

Bryant and Poustie (2001) defined competencies as an observable and applied skills and behaviours that are essential for personal performance and the success of the individual, organization and society. Rastogi, and Malhotra (2013) added that he that is competent in ICT skills finds ICT to be more useful, they approach it with greater confidence and display low anxiety and aversion towards using it. In the same vein, ICT Competencies are a set of technology standards that define proficiency in using computer technology in all sphere of life. Okorafor, (2010) defined ICT competence as a digital literacy that involves skills, knowledge, creativity and attitudes which are necessary in order to cope with learning and with digital media in a knowledge society

Kamba, (2011) asserts that ICT competencies will help both the users of information and the use of technologies in the information search, provision and manageent. Chisenga (2012) stated that there is a need for library users to be trained on how to use the resources, that without such training, the ICT resources cannot be used effectively. Zsakó, and Szlávi (2012) opined that in possessing ICT competencies, you are able to apply basic ICT skills for learning and problem solving in everyday life, at home and work, your knowledge can be applied practically in learning and operating new technologies.

Badaru and Oyegunle (2012) averred that electronic databases also provide unique search features such as searching on multiple criteria (key-word, subject, author, source, classification code, year of publication, language etc.), and variety of display formats \& styles. Okoro (2013) inferred that Internet services are integral part of information communication technology, therefore elements of internet skills is very relevant in all educational curriculum. Gakibayo, Ikoja- Odongo, and 
Okello-Obura (2013) assert that it is imperative that universities/libraries be regularly connected to internet (network) if they are not to be rendered irrelevant in the

\section{Methodology}

The design adopted for this study is descriptive survey with a well structured designed questionnaire in line with the objectives of the study as the instrument used in collecting data. The sample size of the study is 391 derived by using Yamene (1967) statistical formular. Purposive sampling technique was used to select the four study centers libraries used out of six study centers in the south East. Stratified sampling technique was used to select the number of respondent from each study center library, while simple random sampling technique was used to select the individual respondents. A total of 391 modern academic world, for internet is very useful as a communications tool in the universities among librarians and library clientele.

questionnaires were distributed to the students in the four study centre libraries in the South East. A total of 99 questionnaire was distributed to students in Awka study centre, out of which 90 were completed and returned, 98 were distributed to students in Enugu study center, 90 were completed and returned, 98 were distributed to students in Owerri study center, 95 were completed and returned, 96 were distributed to students of Umudike, 90 were completed and returned. A total of 365 were completed and returned from the students. Data collected were analyzed using frequency distribution tables and simple percentages.

\section{Results and Findings}

Table 1: ICT Competencies possessed by Distance Learner's N= 365

\begin{tabular}{|l|c|c|}
\hline ICT Competencies & Frequency & Percentage (\%) \\
\hline Internet Surfing Competency & 99 & 27 \\
\hline Database Competency & 96 & 26 \\
\hline $\begin{array}{l}\text { Word Processing } \\
\text { Competency }\end{array}$ & 87 & 24 \\
\hline ICT Basic Competency & 83 & 23 \\
\hline \multicolumn{1}{|c|}{ Total } & $\mathbf{3 6 5}$ & $\mathbf{1 0 0}$ \\
\hline
\end{tabular}

From the findings in table 1 above, it was observed that majority of the distance learners possess some ICT competencies that can assist them in utilizing the library resources for their academic work. These ranges from Internet surfing competency, which ranks the highest 99 (27\%), followed by database competency 96 (26\%), word 
processing competency $87(24 \%)$ and ICT learners possess internet surfing basic competency $83(23 \%)$. The responses competency. above showed that majority of distance

Table 2: Problems that militate against the Effective Acquisition of ICT $N=365$

\begin{tabular}{|l|c|c|}
\hline Problems & Frequency & Percentage (\%) \\
\hline $\begin{array}{l}\text { The theoretical nature of teaching and } \\
\text { learning of computer }\end{array}$ & 57 & 16 \\
\hline Lack of Finance & 50 & 14 \\
\hline Outdated Computers & 46 & 13 \\
\hline lack of constant power supply & 43 & 12 \\
\hline Lack of internet connectivity & 41 & 9 \\
\hline Broken Computers & 33 & 8 \\
\hline $\begin{array}{l}\text { Lack of knowledge of ICT by parent } \\
\text { community }\end{array}$ & 25 & 7 \\
\hline $\begin{array}{l}\text { Difficulty in integrating ICT into the } \\
\text { Instruction/Syllabus }\end{array}$ & 23 & 6 \\
\hline $\begin{array}{l}\text { Lack of adequate and functioning } \\
\text { computers }\end{array}$ & $\mathbf{3 6 5}$ & $\mathbf{1 0 0}$ \\
\hline Burglary & & 9 \\
\hline
\end{tabular}

The data in table 2 indicated some of the problems that hinder learners from utilizing library resources. The highest number of responses were on the nature of teaching and learning computer 57 (16\%), lack of finance 50 (14\%), outdated computers 46 (13\%), lack of constant power supply $43(12 \%)$, lack of internet connectivity $41(11 \%)$.

The lowest number of responses were on broken computers $33(9 \%)$, lack of knowledge of ICT by parent community 31 (8\%), difficulty in integrating ICT into the instruction/ syllabus 25 (7\%), lack of adequate and functioning computers 23 (6\%) and burglary 16 (4\%). The data above shows that the problems that militate against the effective acquisition of ICT for information retrieval is theoretical nature of teaching and learning computer, due to the high respondent. 
Table 3: Strategies for enhancement $N=365$

\begin{tabular}{|l|c|c|}
\hline Strategies & Frequency & Percentage \\
\hline Constant supply of electricity & 70 & 19 \\
\hline Provision of fund & 62 & 16 \\
\hline $\begin{array}{l}\text { Organization of workshops/orientation } \\
\text { on the use of ICT }\end{array}$ & 54 & 14 \\
\hline $\begin{array}{l}\text { Incorporation of ICT into the school } \\
\text { curriculum }\end{array}$ & 50 & 13 \\
\hline $\begin{array}{l}\text { Use of modern ICT facilities for } \\
\text { teaching and Learning }\end{array}$ & 46 & 12 \\
\hline $\begin{array}{l}\text { Information professionals (Librarians ) } \\
\text { must be ICT minded }\end{array}$ & 44 & 11 \\
\hline $\begin{array}{l}\text { Constant training on ICT programme } \\
\text { for students }\end{array}$ & 39 & $\mathbf{1 0 0}$ \\
\hline
\end{tabular}

Responses as shown in table 3 above indicate some enhancement strategies to the utilization of library resources by distance learners as was indicated as constant supply of electricity $70(19 \%)$, provision of fund 62 (16\%), Organization of workshops/orientation on the use of ICT 54 (15\%), incorporation of ICT into the school curriculum 50 (14\%), use of modern ICT facilities for teaching and Learning 46 (13\%), Information professionals (Librarians)

\section{Recommendations}

The researcher hereby makes the following recommendation deduced from the findings of this study.

1. There should be provision of constant electricity as a basic necessity for the working in and using of ICT facilities.

2. There should be organization of workshops/orientations/seminars/ symposiums on the use of ICT and must be ICT minded 44 (12\%) and Constant training on ICT programme for students 39 $(11 \%)$. From the responses above, it shows that majority of the respondents pointed out constant supply of electricity as an important strategy to enhance effective acquisition of ICT competency for retrieval of library resources. And the least responded suggested is burglary.

its facilities in utilizing library resources.

3. There should be adequate provision of fund from the required authorities.

4. ICTs courses should be incorporated into the programme curriculum.

5. There should be emphasis on the use of modern ICT facilities for teaching and Learning, information professionals (Librarians) must be ICT minded 
6. There should be constant training on ICT programme for both the staff and the students.

\section{Conclusion}

The potential of ICTs in providing equitable access to education is a fact that is widely accepted, it has provided viable platform for adoption and exploitation of knowledge through open and distance education. There is no gainsaying the importance of ICTs to distance learners, hence it provides innumerable opportunities in enhancing the quality and quantity of their academic work, through effective

\section{References}

Afolabi, A.F \& Abidoye, J.A (2011). The Integration of Information and Communication Technology in Library Operations towards Effective Library Services. Journal of Educational and Social Research 1(4) November2011. 114-115 Accessed via

http://www.mcser.org/images/stories/J

ESR-Special-Issues/JESR-

November2011/afolabi-a-f.pdf

Afolabi, A.F \& Abidoye, J.A (2012).The Integration of Information and Communication Technology in Library Operations towards Effective Library Services In Proceedings of the lst International Technology, Education and Environment Conference (c) African Society for retrieval and utilization of library resources. Every institutions libraries ought to invest heavily in ICTs because it produce unquantifiable benefits for their clientele. Despite advances in ICT universities would be posed with complex problems especially in their distance education programs in reaching the already set goal in promoting the development of a knowledgeable society.

Scientific Research (ASSR), Nigeria. 621

Akudolu,L.R.(2006). Quest For Teacher Needed Competencies For Instructional Use of ICT. A Paper presented at the National Conference of Nigerian Primary and Teacher Education Association at Enugu State University of Science and Technology.

Badaru, A \& Oyegunle, J (2012). Impact of ICT on Technical Services, In Library and Information Science Materials. Retrieved via: https://yhoo.it/2X4DsRd

Blurton, C (2002). New Directions of ICTUse in Education. Hong Kong. UNESCO's World Communication and Information Report. 7. Available 
online $\quad$ http://www.unesco.org/education/educprog/lwf/dl/edict.pdf

Chauhan, B.P (2004). ICT Enabled Library and Information Services, Patiala Accessed via http://www.hrpub.org/download/2013 1201/CSIT3-13501205.pdf

Chisenga, J (2004). Libraries: an overview and general introduction to ICT in Libraries in Africa. ICT workshop and Conference paper, Johannesburg

Dodia, D.R (2012). Use of ICT: Required Competency for Teachers. Research Paper In Golden Research Thoughts

Federal Republic of Nigeria (2013). National Policy on Education. Lagos, NERDC. $6^{\text {th }}$ edition 34.

Gakibayo, Anna; Ikoja-Odongo, J. R.; \& Okello-Obura, Constant (2013). "Electronic Information Resources Utilization By Students In Mbarara University Library" Library Philosophy and Practice (e-journal). 6 http://digitalcommons.unl .edu/libphilprac/869

Kamba, M.A (2011). ICT competency framework for library and information science schools in Nigeria: The need for model curriculum In International Journal of Library and Information Science 3(4), 69, 2011 Available online via http://www.academic journals.org/ijlis Accessed on 13th April 2014

Michael, J. (2014). Advantages and disadvantages of ICT. Accessed via http://www.ehow. com on $29^{\text {th }}$ January, 2014

Mole, A. J. C. (2009). Emerging ICT competencies in library and information services: Implications for LIS Education for knowledge societies. In Global Review of Library \& Information Science. (5). 98.

Nwezeh, C. (2010). Libraries and Distance Education in Nigerian Universities: A Revisit. In New Review of Academic Librarianship. Nigeria, Taylor and Francis Group 103.

Oblinger, D.G (2000). The Nature and Purpose of Distance Education: The Technology Source, 2000. Available online at ttp://ts.mivu.org/default.asp.

Oguntuase, F. Z \& Falaiye, Z. M (2004). Meeting Information Needs of rural communities through repackaging of Information. Niger. Library Information Science Review. 22 (1). Retrieved via: http://bit.ly/2YM8opx

Okorafor, A. O (2010). Information and Communication Technology (ICT) Competencies Needed by Tertiary Technical Teachers in South East Nigeria. A Thesis Report Presented to Department of Vocational Education Faculty of Education Nnamdi Azikiwe University, Awka. 11 
Okoro, J (2013). Assessment of Information and Communication Technology Competencies Possessed by University Postgraduate Business Education

Olubor, R.O \& Ogonor, B. O (2008). Quality Assurance in Open and Distance Learning in National Open University of Nigeria: Concepts, Challenges, Prospects and Recommendations. Being paper presented at the $2^{\text {nd }}$ ACDE Conference and General Assembly. 6.

Omoniyi, J. O \& Akinboro, E. O (2009). Repositioning Librarianship, Education and Practice for ICT challenges in Nigerian University libraries. An international journal of ICT: The information Technologists 6(1) 45 -51.

Rastogi, A \& Malhotra, S (2013). ICT Skills and Attitude as Determinants of ICT Pedagogy Integration. In European Academic Research. I (3) India.316. Accessed online via www.euacademic.org

Zsakó, L \& Szlávi, P. (2012) ICT Competences: Algorithmic Thinking. Acta Didactica Napocensia, 5 (2) 4. Retrieved via: http://bit.ly/2X7yEdF.
Students to Handle Entrepreneurship Business Challenges in Nigeria. In Global Journal of Management and 